\title{
Trace element in metamorphic olivine: implications for geothermometry in ultramafic rocks
}

\author{
ELIAS KEMPF, FRANCESCA PICCOLI, JÖRG HERMANN \\ AND DR. THOMAS PETTKE
}

University of Bern

Presenting Author: francesca.piccoli@geo.unibe.ch

Several pressure dependent trace element-in-olivine thermometers have been developed for mantle garnet and spinel peridotites [1]. Yet, there is no systematic study on temperature dependent trace element incorporation into metamorphic olivine. We investigated a suite of samples of olivine-bearing metamorphic serpentinites and peridotites from regional greenschist to amphibolite and eclogite facies conditions.

Low temperature applicability of trace element-in-olivine thermometry was investigated in contact metamorphic serpentinites at the north-eastern part of the Bergell intrusion (Northern Italy) where olivine forming reactions occurred in the originally greenschist facies serpentinites [2]. A detailed trace element study by in-situ LA-ICP-MS revealed that Al shows the most temperature sensitive behavior of all analyzed trace elements, in agreement with previous studies. $\mathrm{Ca}$ is close to the detection limit and $\mathrm{Cr}$ can only be used in order to detect inclusions of spinel type minerals. However, retrograde overprint significantly lowered the $\mathrm{Al}$ content in most olivine grains, such that contact metamorphic olivines can only partially be used for calibration of trace element thermometry.

On the other hand, data from regional metamorphic greenschist and amphibilite to eclogite facies metamorphic olivine show that the $\mathrm{Al}$-in-olivine thermometer is $\mathrm{P}$ independent between $\sim 0.3-3 \mathrm{GPa}$ and $\mathrm{T}$ sensitive from $\sim 500 \pm 25{ }^{\circ} \mathrm{C}$ up to $\sim 850{ }^{\circ} \mathrm{C}$. This thermometer represents a new potentially powerful tool for the investigation of subduction zone metamorphism, barrovian metamorphism, and also for mantle wedge serpentinites and garnet peridotites. The applicability to spinel peridotites of metamorphic and magmatic origin is also further discussed.

[1] DeHoog et al. (2010) Chem. Geol. 270, 196-215.

[2] Kempf (2020) PhD thesis, University of Bern. 